\title{
The longicorn beetle genus Anaglyptus Mulsant, 1839 (Coleoptera: Cerambycidae) in Vietnam, with descriptions of two new species
}

\author{
Жуки-дровосеки рода Anaglyptus Mulsant, 1839 (Coleoptera: \\ Cerambycidae) фауны Вьетнама с описанием двух новых видов
}

\author{
Alexandr I. Miroshnikov ${ }^{1,2}$ \\ А.И. Мирошников ${ }^{1,2}$
}

\footnotetext{
${ }^{1}$ Russian Entomological Society, Krasnodar, Russia. E-mail: miroshnikov-ai@yandex.ru

${ }^{2}$ Sochi National Park, Moskovskaya str., 21, Sochi, Krasnodar region 354002, Russia.

${ }^{1}$ Русское энтомологическое общество, Краснодар, Россия

${ }^{2}$ Сочинский национальный парк, ул. Московская, 21, Сочи, Краснодарский край 354002, Россия.
}

KEY WORDS: Coleoptera, Cerambycidae, Anaglyptini, Anaglyptus, Vietnam, review, new species, key to species.

КЛЮЧЕВЫЕ СЛОВА: Coleoptera, Cerambycidae, Anaglyptini, Anaglyptus, Вьетнам, обзор, новые виды, определительная таблица.

ABSTRACT. All four species of the genus Anaglyptus Mulsant, 1839 currently known from Vietnam are discussed. Two of them, namely, A. kabakovi sp.n. and $A$. trocolii sp.n., are described as new. A key to the Vietnamese species and pictures of the holotypes of the new taxa are given.

РЕЗЮМЕ. Рассматриваются все четыре вида рода Anaglyptus Mulsant, 1839, известные с территории Вьетнама. Два из них, а именно, A. kabakovi sp.n. и A. trocolii sp.n., описываются как новые. Приведена таблица для определения вьетнамских видов. Даны фотографии голотипов новых таксонов.

\section{Introduction}

Until now, only two species of the genus Anaglyptus Mulsant, 1839 have been known to occur in Vietnam, one of these described just a few years ago [Holzschuh, 2011], the other only recently transferred to this genus from Oligoenoplus Chevrolat, 1863 [Viktora, 2014].

This work describes further two species. Thus, the fauna of Vietnam currently contains four species of Anaglyptus, although there can hardly be any doubt that eventually it is more diverse. This is especially plausible because species of this genus occur in not only in the northern part of the country, but also in the south.

The material this paper is based upon comes from the following institutional and private collections:

MNHN - Muséum national d'Histoire naturelle, Paris, France;

ZISP - Zoological Institute of the Russian Academy of Sciences, St. Petersburg, Russia;

cAM - coll. Alexandr Miroshnikov (Krasnodar, Russia);
cCH - coll. Carolus Holzschuh (Villach, Austria); cST- coll. Sergi Trócoli (Gracia, Barcelona, Spain).

\section{Anaglyptus kabakovi Miroshnikov, sp.n.} Figs 1, 3-5

MATERIAL. Holotype + (ZISP), N Vietnam, $50 \mathrm{~km}$ NE Thai Nguyen, 300 m, 06.III.1962, O. Kabakov leg.; paratype + (cAM), same label.

DIAGNOSIS. By the character of setation of the pronotum, antennomeres $7-8$, metatibiae and metatarsi, as well as by the pattern of the elytra, this new species differs very clearly from all congeners and, in combination with some other features described below, it is easy to diagnose.

DESCRIPTION. Female. Body length $8.0-8.5 \mathrm{~mm}$, humeral width $1.9-2.1 \mathrm{~mm}$. Head, prothorax almost entirely, elytra, mesosternum mostly, scutellum, metasternum completely black; elytra in basal half over a significant part, including the very base together with humeri, on sides and a broad fascia before middle, and in apical half under fascia of light setae at the beginning of last one-third yellowish reddish, this together with a generally black coloration forming a peculiar pattern, as in Fig. 1; genae apically, antennomere 1 in apical part, antennomere 2 entirely, antennomere 3 at the very base and very apex, prothorax at the very base, apical margin of elytra, including spines, mesosternum partly in apical half, first (visible) sternite completely, rest (visible) sternites at the very base, legs partly reddish and yellowish-reddish tones; antennomere 1 in basal part, antennomere 3 almost entirely, antennomeres 4-6 completely, visible sternites except for first sternite almost entirely, sometimes most of femora from below brownblack; antennomeres 7-9 except for reddish base of antennomere 7 pale yellow; antennomeres 10-11 except for light base of antennomere 10 brown; legs this or that way partly infuscate.

Head with poorly developed antennal tubercles; antennae slightly longer than body, extended behind apex of elytra by penultimate antennomere; antennomere 2 strongly 


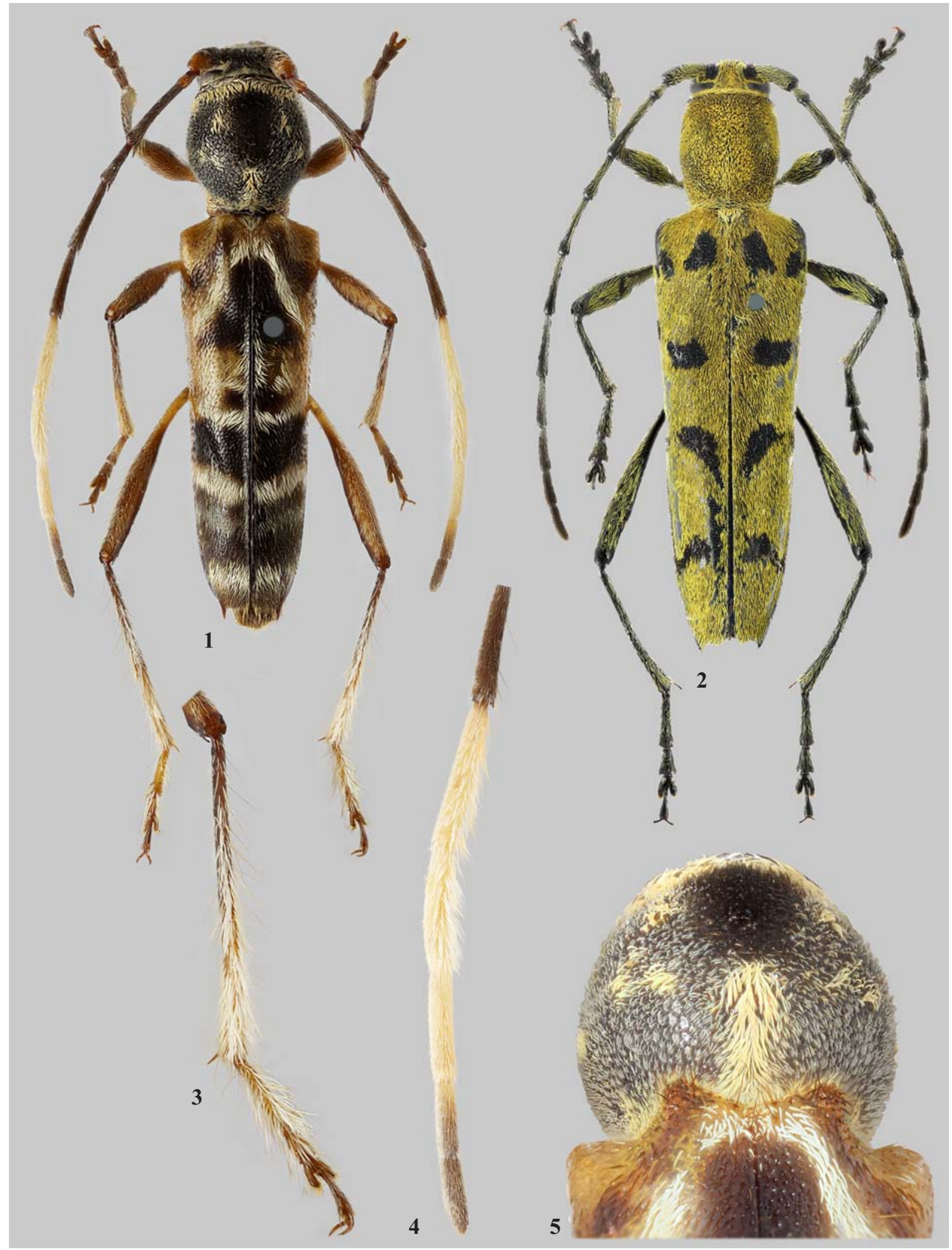

Figs 1-5. Anaglyptus ssp.: 1, 3-5-A. kabakovi sp.n., holotype, female; 2 -A. trocolii sp.n., holotype, male; $1-2$ - habitus; 3 - right metatibia and metatarsus; 4 - left apical antennomeres; 5 - pronotum and base of elytra, posterodorsal view.

Рис. 1-5. Anaglyptus ssp.: 1, 3-5 - A. kabakovi sp.n., голотип, самка; 2 - A. trocolii sp.n., голотип, самец; 1-2 - общий вид; 3 голень и лапка правой задней ноги; 4 - вершинные членики левого усика; 5 - переднеспинка и основание надкрылий, сзади и сверху. 
longitudinal; antennomere $3,1.60-1.71$ times as long as antennomere 4; length ratio of antennomeres 1-11 (holotype taken as an example), 55: 19: 77: 45: 71: 68: 80: 65: 60: 41: 45; apical external angle of antennomeres 3-6 each with a spine, very long in $3^{\text {rd }}$, shortest in antennomere 6 .

Pronotum globular, barely longitudinal; at apex slightly wider than at base; strongly convex; on sides strongly rounded; with a rough, very dense and confluent puncturation forming predominantly clear, cellular sculpture.

Scutellum elongated, triangular, sharpened at apex.

Elytra moderately narrowed towards apex; 2.88-2.95 times as long as humeral width; base very strongly tuberculiform elevated (Fig. 5), each elytron there with a strongly, keel-shaped, longitudinal, short tubercle starting from the very base; apical external angle extended into a long tooth; with a clear, moderately dense, weakened towards apex puncturation.

Prosternum predominantly with a transversely wrinkled, partly heterogeneous sculpture; mesosternum with a rough, partly more or less sparse puncturation; metasternum mostly with relatively small punctures, next to metepisterna with a much coarser puncturation; first (visible) sternite with sparse, irregular, rough punctures, rest (visible) sternites with a much more numerous and denser puncturation; last (visible) sternite widely rounded at apex.

Legs long; metafemora clearly extended behind apex of elytra; profemora slightly claviform, meso- and metafemora not claviform; metatarsomere 1, 1.45-1.47 times as long as next two metatarsomeres combined.

Dense recumbent setation mostly white and only partly yellowish white; on prototum forming a very clear, relatively broad fascia at apex, a less distinct fascia at base, a median longitudinal strip in basal one-third, two pairs of symmetrical shapeless spots on either side of median line, thereby one pair before middle, the other pair behind middle, as in Fig. 1, thus generally forming a peculiar pattern unknown in other congeners and basically uncharacteristic of Anaglyptus. Besides this, disk of pronotum clothed with suberect, relatively dense, black setae forming a large, longitudinal, broad, posteriorly narrowed spot, the latter starting almost from apex and extending about $2 / 3$ of pronotum length to median longitudinal light strip in basal one-third; remaining pronotum surface with gentle, white setae not obscuring its sculpture; elytral pattern of fasciae, as in Fig. 1, also peculiar; surface of elytra devoid of light setae, being covered instead by black recumbent ones; antennomeres $7-8$, metatibiae except for base and metatarsomeres 1-2 clothed with dense, long, suberect, partly almost recumbent, white setae generally forming a peculiar lush setation (Figs 3,4) seemingly not observed in other Anaglyptus species; antennomere 9 clothed with a moderately long, antennomeres $10-11$ with shorter, recumbent, white setae; the most dense white recumbent setation on venter restricted to mesepimera, mesepisterna, predominantly in apical part of metepisterna, to sides of first (visible) sternite apically, to basal part and to sides of next two (visible) sternites; long, erect or suberect, sparse, light setae most abundant on head, antennae and venter, on elytra present only in basal one-quarter, on pronotum predominantly on sides.

Male unknown.

DISTRIBUTION. Northen Vietnam. Known from a single locality.

ETYMOLOGY. The new species is named in the memory of the famous Russian entomologist, a remarkable collector of beetles, Dr. Oleg Nikolaevich Kabakov.

\section{Anaglyptus trocolii Miroshnikov, sp.n.}

Fig. 2

MATERIAL. Holotype $\sigma^{\top}$ (cST) (14893), N Vietnam, Lao Cai Prov., Sa Pa (= Sapa) env., 1800 m, VI.2014, S. Trócoli leg.

DIAGNOSIS. This new species seems to be especially similar to A. flavus Viktora, Tich1 et Rapuzzi, 2013, but differs clearly by the almost entirely monochrome black integument of the body, antennae and legs, the presence of a clear tubercle at the base of each elytron, the longer antennae (at least so in the male), and a somewhat different ratio of antennomere lengths. A. trocolii sp.n. is also very similar to $A$. tichyi Miroshnikov, Bi et Lin, 2014 and A. annulicornis (Pic, 1933), but differs from both by the clearly longer antennae (at least so in the male), the somewhat different elytral pattern, especially the shape of spots behind the middle of the elytra, the slenderer and longer legs; moreover, from $A$. tichyi it differs by the much less strongly developed tubercle at the base of each elytron, from $A$. annulicornis by the presence of this tubercle, as well as by the shape of the pronotum, including less strongly rounded sides and the absence of black spots on its disk.

DESCRIPTION. Male. Body length $13.0 \mathrm{~mm}$, humeral width $3.4 \mathrm{~mm}$. Black; antennomeres 8-11 brown-black.

Head with well-developed antennal tubercles; antennae freely extended behind pre-apical black fascia of elytra; antennomere 2 slightly longitudinal; antennomere 3, 1.51 times as long as antennomere 4; length ratio of antennomeres 1-11, 52: 16: 65: 43: 55: 54: 55: 44: 38: 32: 35; apical external angle of antennomere 3 with a well-expressed, but not long spine, antennomere 4 with a small, but evident one.

Pronotum clearly longitudinal; at apex barely wider than at base; moderately convex; slightly rounded at sides; in basal part of disk with a very weak keel-shaped elevation; with a coarse, very dense and confluent puncturation almost completely hidden under a dense recumbent light setation.

Scutellum longitudinal, triangular.

Elytra elongated, moderately narrowed towards apex, 3.0 times as long as humeral width; base of each elytron with a clear (but not so strongly as in $A$. tichyi), longitudinal, short tubercule; apical external angle extended into a moderately long tooth; with a small, dense, weakened only towards apex puncturation.

Mesosternal process about 3 times as broad as prosternal process between procoxae; last (visible) sternite at apex with a well-developed, broad emargination; venter with a small, partly heterogeneous puncturation.

Legs relatively long; metafemora distinctly extended behind pre-apical black fascia of elytra; profemora moderately claviform, mesofemora weakly claviform, metafemora not claviform; metatarsomere 1 slightly longer than next two metatarsomeres combined.

Recumbent dense setation on dorsum yellow, completely covering head and pronotum, on elytra forming a spotty pattern resembling that in A. flavus, as in Fig. 2, thereby black spots covered also by black dense setae; recumbent setation on venter entirely dense, yellow, but lighter than on dorsum; basal antennomeres and legs partly clothed with a more or less dense, recumbent, yellow or yellowish setae, remaining antennomeres except for two last partly, including base, covered by a dense, recumbent, white pubescence; most of antennomeres, starting with antennomere 1, mostly on inner side with long, erect or suberect setae; head, pronotum partly on sides, base and apex of elytra, venter, partly also legs clothed with more or less long, sparse, erect or suberect, thin setae.

Female unknown.

DISTRIBUTION. Northen Vietnam. Known from a single locality. 
ETYMOLOGY. The new species honours my colleague Mr. Sergi Trócoli (Gracia, Barcelona, Spain), who collected the holotype.

Anaglyptus rufogriseus (Pic, 1928)

Demonax rufogriseus Pic, 1928: 18. Type locality: S Vietnam, Da Lat (= Dalat) (according to the original description and the label of the holotype).

Anaglyptus rufogriseus: Viktora, 2014: 224, figs 21a, b.

MATERIAL. Holotype + (MNHN) (photograph), "[Vietnam] Dalat, 4.III.[19]24"; "Demonax rufogriseus n.sp."; "type".

DISTRIBUTION. Southen Vietnam. Known from a single locality: Lam Dong Province, Da Lat (= Dalat) [Pic, 1928; Viktora, 2014].

\section{Anaglyptus graphellus Holzschuh, 2011}

Anaglyptus graphellus Holzschuh, 2011: 318, Abb. 61a, b. Type locality: NE Laos, Hua Phan Prov., Phou Pan Mt, Ban Saleui, $1300-1900 \mathrm{~m}, \sim 20^{\circ} 12^{\prime} \mathrm{N} / 104^{\circ} 01^{\prime} \mathrm{E}$ (according to the original description)

Anaglyptus graphellus: Miroshnikov et al., 2014: 256, pl.5, fig.5.

MATERIAL. Holotype $\sigma^{7}(\mathrm{cCH})$ (photograph) and paratype (cCH) (photograph), NE Laos, Hua Phan Prov., Phou Pan Mt, Ban Saleui, 1300-1900 m, 20²1'N / 104001'E, 1.VI.2011 (C. Holzschuh leg.).

DISTRIBUTION. Northen Vietnam and northen Laos. In Vietnam known from a single locality: Lao Cai Province, Fansipan (= Fan Si Pan) Mt, 3 km NW Cat Cat, $2000 \mathrm{~m}$ [Holzschuh, 2011].

\section{Key to Vietnamese SPECIES OF ANAGLYPTUS}

1. Each elytron at base with a clear, but not strong, longitudinal, short tubercle, or without it; pronotum not globular, without clear spots and fasciae of dense, recumbent, light setae; metafemora noticeably or far from reaching apex of elytra; spine at apex of antennomere 3 clearly shorter or quite invisible .. 2

- Each elytron at base with a strong, longitudinal, short tubercle, starting from the very base; pronotum globular, with well-expressed spots on disk and apical fascia of dense, recumbent, light setae (Fig. 1); metafemora clearly extended behind apex of elytra; apex of antennomere 3 with a very long spine (at least so in female) A. kabakovi sp.n.
2. Integument of antennae, legs and body at least mostly brown and red-brown tones; dense, recumbent setation without yellow coloration ....

- Integument of antennae, legs and body almost completely black; dense, recumbent setation mostly yellow (Fig. 2) A. trocolii sp.n.

3. Dark pattern of elytra forming only a longitudinally roundish spot at base of each elytron and a spot fascia before middle, clearly not reaching suture; antennae less robust A. rufogriseus (Pic)

- Dark pattern of elytra forming a clear fascia (but not a spot) at base and an X-shaped fascia near middle, reaching or almost reaching suture; antennae more robust ....

A. graphellus Holzschuh

ACKNOWLEDGEMENTS. I am very grateful to Andrey L. Lobanov (ZISP) for the opportunity to study the museum material while Sergi Trócoli has provided some specimens from his private collection. My sincere thanks also go to Kirill V. Makarov (Moscow Pedagogical State University, Russia) who helped with the preparation of the photographs and to Luboš Dembický (Brno, Czech Republic) for his provision of the pictures of the holotype and paratype of Anaglyptus graphellus.

\section{References}

Holzschuh C. 2011. Beschreibung von 69 neuen Bockkäfern und 6 neuen Gattungen aus Asien, vorwiegend aus Borneo, China, Laos und Thailand (Coleoptera, Cerambycidae) // Entomologica Basiliensia et Collectionis Frey. Bd.33. S.249-328.

Miroshnikov A.I., Bi W.-X., Lin M.-Y. 2014. New or little-known species of the genus Anaglyptus Mulsant, 1839 (Coleoptera: Cerambycidae) from China // Caucasian Entomological Bulletin. Vol.10. No.2. P.255-259. Col.pls.5-8.

Pic M. 1928. Nouveautés diverses // Mélanges Exotico-Entomologiques. Fasc.52. P.1-32.

Viktora P. 2014. Contribution to knowledge of the Clytini Mulsant, 1839 and Anaglyptini Lacordaire, 1869 (Coleoptera: Cerambycidae: Cerambycinae) from the Oriental and Australian Regions // Studies and Reports. Taxonomical Series. Vol.10. No.1. P.205-226 